\title{
Analysis on Financial Support of the Development of China's Economic Transformation in a New Situation
}

\author{
Hongli Peng \\ School of Economics and Management, Chuxiong Normal University, Chuxiong, Yunnan, China \\ Email:mlbsabc@sina.com
}

How to cite this paper: Peng, H.L. (2017) Analysis on Financial Support of the Development of China's Economic Transformation in a New Situation. Modern Econo$m y, 8,249-255$.

https://doi.org/10.4236/me.2017.82017

Received: January 19, 2017

Accepted: February 21, 2017

Published: February 24, 2017

Copyright $\odot 2017$ by author and Scientific Research Publishing Inc. This work is licensed under the Creative Commons Attribution International License (CC BY 4.0).

http://creativecommons.org/licenses/by/4.0/

\section{(c) (i) Open Access}

\begin{abstract}
The reform and opening-up policy prompts a rapid development of our social economy, science and technology, while the development of financial system plays an irreplaceable role in economic development. Our nation is in the key period of economic transformation. The financial support system, which can provide guarantee for rapid and stable economic transformation, is important in order to provide better economic services. It mainly includes banking system, security system and financial intermediaries. This paper analyzes the current status of financial support under the condition of economic transformation, puts forward the financial support measures for the development of China's economic transformation and lays a good foundation for building a good folk financial market environment.
\end{abstract}

\section{Keywords}

Economic Transformation, Financial Support, Current Status, Measures

\section{Introduction}

The economy of our nation is in a new situation as in the key period of economic transformation, and a Sound financial system provides a good financial environment for economic development and economic transformation. It can promote the economic transformation in a positive way by using the financial system. Economic development in different stages has very important influence on development of financial intermediaries and financial market. And it has direct impact on economic development and on realizing the economic transition and the building of a well-off society in an all-round way. Financial development has important effect on economic development, while financial development connects with economic development closely. Economic development in different 
stages can affect financial development directly and financial development in different stages can also affect economic development directly. The reform and opening-up policy promotes China's rapid economic growth [1].

The development of financial system provides great support to the Chinese economy. Considering our nation is in the key period of economic transformation, we need to make measures in combination with the practical situation of financial support. Due to the great effect of agriculture on economic development, we should promote China's economic transformation through rural economic transition. As the core power of economic development, the internal competition of financial industry is becoming more and more intense, so it is the key for economic development to build a better financial system. This paper analyzes the current situation of China's economic transformation, and then provides some financial support measures in economic transformation under the new economic situation.

\section{The Current Situation of the Development of Financial Support in Economic Transformation}

\subsection{The Overall Situation of Financial Support}

The rapid development of science and technology promotes the social and economic development. China has got rid of the development limitation of the traditional planned economy gradually, and realized the effective transformation of market economy. The economic situation develops in a more scientific way, which plays an important role in the sustainable development of economy. As China's general development trend impels the rapid growth of financial industries, the financial industry demonstrates richness, and financial products functions also gradually improve at the same time, which helps to improve the actual allocation efficiency of financial enterprise resources. In fact, there are still many problems in China's financial support, such as the discordance of the actual risk control level, the unbalance between regional economy and economic structure and the real economy unbalanced service efficiency [2]. The financial ratio affects financial support directly, but still has large gap between them.

\subsection{Analysis on the Bank's Development Situation}

According to the analysis on the current situation of financial support development, China still takes indirect financing as the major financing way since the indirect financing accounts for nearly $57 \%$ of the whole financing. But the commercial banks are leading the indirect financing system while credit funds are the main form of indirect financing. Considering the superiority of management mode of stock-holding banks, especially the superiority of performance evaluation and excitation mechanism, the actual development speed of stock-holding banks is very quick. In the development process of China's banking system, the debt of the state-owned bank assets and state-owned assets still has great effect. Especially in recent years, the development of municipal commercial banks adjust the market interest rates gradually, so the obvious advantages of regional 
development influence the effect of bank management. Besides, other deposit financial institutions also bring huge impact on traditional banking system, which affects the development of banking system greatly and can create good financial competition environment for financial institutions as a result.

\subsection{The Analysis on the Situation of Securities Market Development}

From the current development situation, financial development has reached a high level, but still exist many problems in the actual development process, especially that the financing system is not perfect and the way of financing system is single. At present, the banking system regards indirect financing as the key financing channel. Combined with the development of stock market and bond market in recent years, the transformation of traditional financial management mode significantly increased the volume of direct financing. But compared to the developed western countries, the proportion of quantity of direct financing is still low. With the further development of financial products system in our country, we need to improve the innovation and imitation abilities of financial products, raise the actual level of financing industry, give full play to the market orientation, effectively meet the investors' demands in products and services, and provide protection to the enrichment and diversification of financial products [3].

\subsection{The Current Situation of Development of Financial Intermediaries}

The financial institutions develop rapidly in both quantity and quality. And it helps to build a set of relatively perfect regulation system, such as the regulatory structure of people's bank, China Banking Regulatory Commission, China Insurance Regulatory Commission and so on. In fact, the various regulatory agencies have very clear division of labor, and the contents and scope of supervision inter wine, so they can form partnership. The importance of non-bank financial institutions should also be considered, such as security institutions, insurance companies and trust institutions, which can reach the pluralism phase of co-existed intermediary institutions of various kinds. But as banks is still the main body of financial institutions, and it lacks a relatively perfect structure, so the relatively perfect financial system and solid investment financial system have not been built, and the financial support lacks risk control methods in high level.

\section{China's Financial Support Measures in Economic Transformation under New Situations}

\subsection{To Do a Good Job of IPO Mechanism}

The system of issuing new shares in our country is still in the process of constant changes. It not only experienced examination system, but also experienced the approval system. Under the effect of market economy, the problems of securities market are becoming prominent, companies have big difficulties in financing, 
and investors themselves lack clear investment directions. In order to solve the problems in securities market, a registration system appears gradually in the new share discovery system. The registration system means that the applicant of issued shares can open share issue related information according to law and make it into normative legal documents, while the management institutions should review legal documents according to the program, and decide whether the information of the applicant of issued shares can meet relevant provisions. At present, most of the relatively economic developed countries like USA, Great Britain, Canada and Singapore choose the registration system. To choose the registration system when issuing a stock has significant advantages. The smalland-medium-sized enterprises can expand financing channels by using the registration system, which has much influence in the enterprise development. For the moment, the financing difficulty is the problems that the small-and-medium-sized enterprises face, because the small-and-medium-sized enterprises are unable to get loans due to their own practices. The registration system can help the small-and-medium-sized enterprises to get loans since they can finance as long as their strength comply with relevant regulations. The registration system can also promote the relevant administrative departments delegate powers to a lower level gradually. In the past, government departments affect whether a company can go public, now companies themselves can decide it after the registration system is carried out. It can create a good competition environment for the companies. In short, registration system can provide a better financing platform and rich securities market gradually for IPO [4].

\subsection{Build a Diversified Financial System}

The building of a diversified financial system is beneficial to adjust the financial structure. At present, the banking system is still main body in the current financial structure. But the financial structure restrains the economic transformation in China to some extent, so the diverse financial system is needed in order to adjust the financial structure effectively and promote the economic transformation. China need to build a multi-level capital market so as to promote the harmonious development between financial infrastructure market, capital market, money market and bond market, effectively meet the needs of enterprises in financing, and continuously reduce the cost of enterprises in direct financing. At the same time, the innovation financial products should be encouraged. Under the condition of reasonable control risk, the richness of species of financial products can meet the individual needs of diversified investors and improve the motivation and creativity of the financial products. Therefore, the reform of financial system is very important. Governments can encourage private enterprises to participate in the share of commercial Banks or directly enter the bank industry, increase the number of private capital bank, prompt private capital to be invested in the financial sector, give full play to private capital, enhance efficiency of the financial system, and effectively promote the development of the real economy. In addition, governments can also encourage non-financial institu- 
tions such as financial company, trust company and other kinds of companies to enhance the competition force of financial industry by providing financial services, then innovate financial products, like various network payment including We chat pay and Alipay, which has irreplaceable function to improve the quality and efficiency of financial services.

\subsection{Realize the Coordinated Development of Financial Industry and Rural Financial System}

The governments should recognize the important role of rural finance in the development of the financial industry and strengthen support to rural financial system to make the harmonious developments between the rural financial system efficiency, the scale of the financial system and financial system structure. Judging from the present condition, the rural financial system is still at a low stage of development although rural financial system has begun to take shape. It has very important effects on rural economic development and on the real credit development. To make better development of rural financial system, governments need to gradually strengthen support to rural financial development, encourage rural financial innovation under the condition of controllable regulation, build a multi-level rural financial market system, enhance rural financial risk control ability, and promote the coordinated development between various financial system including rural credit cooperative, rural insurance and banking institutions and so on, then provide diversified financing channels to the development of rural economic entities and improve the service efficiency of country side funds. In the construction process of the rural financial system, we need to give full play to the regional development advantage, attach great importance to the regional network construction, and plan financial network rationally by considering the network radiation radius. Meanwhile, regulators also should give full play to their own roles, increase training for rural financial structure and for targeted risk control and management combining with the characteristics of rural financial structure, enhance risk control consciousness of rural financial institutions and management efficiency, attach great importance to the training on service consciousness of rural financial institutions, improve the actual service levels and real competitiveness of rural financial institutions by combining with the advantages of regional network.

\subsection{Improve Operation Effectiveness of Financial Structure System}

In order to improve actual operation efficiency of financial institutions, the importance of resources allocation should be noticed. The financial system operating efficiency mainly includes two aspects-the banking system and indirect financial system, so we should build indirect financial system while the banking system play the main role. And we need to gradually improve the running efficiency of the financial institutions, play the market leading role, adhere to the management security, profitability and liquidity, optimize the configuration of 
resources. Combined with the national industrial development policy, funds should be allocated rationally so as to offer high-quality service to the real economy and promote adjustment and optimization of industrial structure. Considering the important functions of operating efficiency of direct financing system, the overall scale of capital market should be expanded starting from the bond market and stock market and multi-level market system and finance system should be constructed. Effective financing channels should be chosen according to difference between various enterprise qualifications and enterprise credit levels. Due to different investors' risk enduring capabilities, diversified market investment channels should be built so that a more perfect capitalism financing market could be established, then the actual cost of investment and financing could be reduced, the burden of issuers and investors could be relieved, and finally enhance vitality of direct investment system and promote better development of the real economy [5].

\subsection{Combine Government's Guidance and Market's Dominant Function}

According to the development situation of the economic transformation, market plays a dominant role during the process of the rural financial development. But as the same time, the government's guide function should also be realized and the supervision work should be considered important. Interest rate restrictions could be eased as much as possible under the condition of combining with the actual market situation. Rural finance is still in the primary stage, we should match the operating risk of financial structure and handling rates of financial institutions in order to compensate for the high risk and cost of rural finance, expand the development space and living space of rural finance as much as possible, enlarge the capital scale of rural financial institutions, and meet the needs of rural credit effectively. The government should play a guiding role and give some policy support. The government's guiding function for rural finance should be strengthened gradually to provide high quality financial services to the rural real economy. The rural economic support can be strengthened through the finance policy and the problem of rural savings outflow can be avoided as far as possible. Regulators should make clear of their regulatory functions, improve the risk enduring abilities of rural finance, and realize the problems of low ability of rural finance against risk and of the low-threshold, prompt the foster, guide and supervision work of rural finance in order to provide high quality services, avoid all kinds of financial risks, promote rural economic transition and provide security for the interests of rural investors.

\section{Conclusion}

The rapid development of financialization economy is becoming more and more important in the macroeconomic control. So we should respect the important function of central bank, choose a more scientific monetary policy according to actual situations of economic transformation development and of the economic 
structure adjustment, and promote economic growth on the basis of currency stability. At present, most of the financial regulations control economy by using bank rate and required reserves. The control of credit scale is still the main body. Banks should create good conditions in the actual development process, attach great importance to the credit management work, achieve indirect regulations by using a comprehensive policy and provide guarantee for currency stability. Rapid development of rural finance promotes rapid economic development in our country; but rural economic development is still at the primary stage, rural finance efficiency and scale are still at a low level, and it lacks risk enduring capabilities, which lead to the result that rural economic development is not ideal. In a word, we should consider actual situation of rural finance development, give full play to the regulatory functions in the process of economic transformation development, combine development with regulations, build more perfect finance support policy in order to better promote economic transformation. This paper provides some effective and comprehensive measures, such as improving IPO mechanism, building a diversified financial system, realizing the coordinated development of financial industry and rural financial system, improving operation effectiveness of financial structure system and combining government's guidance and market's dominant functions, which will all contribute to China's economic development in a quicker and healthier way.

\section{References}

[1] Li, M. (2014) Research on China's Financial Support under Economic Transformation. Beijing University of Technology, Beijing.

[2] Li, B.Y. (2014) Research on Financial Support of China's Economic Transformation Upgrading. East China Normal University, Shanghai.

[3] Zhou, Y.Q. (2012) Analysis on Financing Problems of Small and Medium-Sized Enterprises in Our Country during Economic Transformation Period. Jiangxi University of Finance and Economics, Nanchang.

[4] Wu, X.S. (2008) Research on Financial Development and Dual Economic Transformation. Nanjing Normal University, Nanjing.

[5] Liu, R.W. (2011) An Empirical Analysis of the Financial Support to the Transformation of Economic Development in Zhejiang Province. Zhejiang Finance, 12, 4-9. 
Submit or recommend next manuscript to SCIRP and we will provide best service for you:

Accepting pre-submission inquiries through Email, Facebook, LinkedIn, Twitter, etc. A wide selection of journals (inclusive of 9 subjects, more than 200 journals)

Providing 24-hour high-quality service

User-friendly online submission system

Fair and swift peer-review system

Efficient typesetting and proofreading procedure

Display of the result of downloads and visits, as well as the number of cited articles Maximum dissemination of your research work

Submit your manuscript at: http://papersubmission.scirp.org/

Or contact me@scirp.org 